\section{Influence of Apical Enlargement in Cleaning of Curved Canals Using Negative Pressure System}

Karina Torales Lorencetti, Yara Teresinha Corrêa Silva-Sousa, Gabriel Elias do Nascimento, Danielle Cristine Furtado Messias, Vivian Colucci, Fuad Abi

Rached-Junior, Silvio Rocha Corrêa Silva
Dental School, University of Ribeirão

Preto, Ribeirão Preto, SP, Brazil

Correspondence: Prof. Dra. Yara

Teresinha Corrêa Silva-Sousa, Rua

Célia de Oliveira Meirelles, 350,

14024-070 Ribeirão Preto, São

Paulo, Brasil. Tel: +55-16-3603-

6763. e-mail: ysousa@unaerp.br
This study aimed to evaluate, by scanning electron microscopy (SEM), the cleaning of canal walls with moderate curvature subjected to biomechanical preparation with different final diameters using apical negative pressure irrigation. Thirty-two mesiobuccal roots of molars were divided into 4 groups $(n=8)$ according to the instrument's final diameter: $\mathrm{Gl}: 30.02$, GII: 35.02, GIII: 40.02 and GIV: 45.02 . Irrigating procedure was performed at each change of instrument with $1 \% \mathrm{NaOCl}$ using the Endovac system. Final irrigation was conducted with 17\% EDTA for $5 \mathrm{~min}$. The SEM photomicrographs were evaluated under $35 x$ and $1000 \times$ magnification, by three calibrated examiners, in a double-blind design. Data were submitted to Kruskal-Wallis and Dunn's post hoc tests $(\alpha=0.05)$. Canals instrumented with 30.02 and 35.02 final diameters showed more debris, statistically different from the other groups $(p<0.05)$. Comparing each root canal third, for the cervical and apical portions no statistically significant difference ( $p>0.05$ ) was found among the four groups. Regarding the presence of smear layer, canals with 30.02 final diameter showed the highest scores, statistically different from the 45.02 group $(p<0.05)$ and similar to the 35.02 and the 40.02 groups ( $p>0.05$ ). Although none of the studied diameters completely removed debris and smear layer, it may be concluded that instrumentation with higher final diameters was more effective in cleaning the root canals with moderate curvature.
Key Words: endodontics, debris, smear layer, scanning electron microscopy.

\section{Introduction}

The development of NiTi rotatory instruments has enabled the use of instrumentation protocols that allow greater apical enlargement of curved canals with minimal deviation $(1,2)$. However, anatomic variations in the root canal system remain as limiting factors to adequate cleaning and they favor retention of residual tissue and bacteria in the isthmuses, dimples, lateral and apical ramifications and flattened areas. Thus, despite technological advances related to endodontic instruments, all instrumentation techniques leave untouched $35 \%$ or more of the canal surface (2-4). This fact increases the importance of using chemical solutions able to dissolve organic and inorganic tissues (5), as well as irrigating techniques that promote increased solution flow (6) like the apical negative pressure systems.

Considering the protocols that advocate increasing the final diameter in curved canals and different irrigating techniques, the present study aimed to evaluate by SEM the influence of final apical diameter enlargement, associated with an apical negative pressure irrigation system, for cleaning root canals with moderate curvature.

\section{Material and Methods}

This study protocol was reviewed and approved by the Ethics Committee of the University of Ribeirão Preto.
Thirty-two human first molars were selected according to the methodologies proposed by Schneider (7) and Pruett et al. (8), respectively. From digital pictures obtained by VixWin system (Gendex Dental Systems, Hatfield, PA, USA), mesiobuccal root canals had their angle and radius of curvature measured and those with mild curvature (equal to or less than $10^{\circ}$ ) were chosen.

After the teeth selection, the canal was explored to its full extent using a \#8 K-file (Dentsply-Maillefer, Ballaigues, Vaud, Switzerland) until the tip coincided with the apical foramen. One millimmeter was reduced from the found measurement, in order to determine the real working length. The tooth was adapted and stabilized on a condensation silicone base (Perfil Vigodent, Rio de Janeiro, RJ, Brazil) to promote apical negative pressure in a closed system during irrigation with EndoVac (Discus Dental, Culver City, CA, USA).

The roots were divided into 4 groups $(n=8)$, according to the surgical diameter. The instrumentation of the root canals started with manual \#8, \#10, \#15 and \#20 K-file instruments (Dentsply-Maillefer) until the real working length and continued with $\mathrm{K} 3 \mathrm{NiTi}$ rotatory system (SybronEndo, Orange, CA, USA), by the Free Tip Preparation technique. The sequence of instruments in each group was 
established as follows: Group I: $25.12,25.10,25.08,25.06$, $25.02,25.04,25.06,30.02$. Group II: full-sequence of Group I plus 30.06, 25.06 and 35.02. Group III: all sequencing instruments used in Group II plus 25.06 and 40.02. Group IV: all instruments of Group III plus 25.06 and 45.02.

Irrigating procedure was carried out using the EndoVac system (Discus Dental). At each change of instrument, $5 \mathrm{~mL}$ of $1 \% \mathrm{NaOCl}$ solution was inserted in the cervical third of the canal via master delivery tip cannula. After $30 \mathrm{~s}$, the solution was aspirated with the macro-cannula placed 2 $\mathrm{mm}$ from the real working length. After the last irrigation cycle, a final irrigation with $1 \% \mathrm{NaOCl}$ was performed for 30 s. The micro-cannula alternated corono-apical movements remaining for $5 \mathrm{~s}$ at a $2 \mathrm{~mm}$ distance from the real working length in specimens from Group 1. In the other groups, a micro-cannula was inserted for $5 \mathrm{~s}$ in the real working length and after that time it was maintained for $5 \mathrm{~s}$ at 2 $\mathrm{mm}$ below the real working length. A cycle of macro- and micro-irrigation was performed with 17\% EDTA for 5 min.

After irrigation with EDTA, neutralization was

Table 1. Scores used to determine removal of debris and smear layer

\begin{tabular}{|c|c|c|}
\hline Score & Debris & Smear \\
\hline 1 & Clean walls, without debris. & Absence of smear and open dentinal tubules. \\
\hline 2 & Walls with little scattered debris. & $\begin{array}{l}\text { Smear layer covering up to } 50 \% \text { of the surface } \\
\text { and several open dentinal tubules. }\end{array}$ \\
\hline 3 & $\begin{array}{l}\text { Walls with debris clusters covering } \\
\text { less than } 50 \% \text { of the surface. }\end{array}$ & $\begin{array}{l}\text { Smear layer covering more than } 50 \% \text { of the } \\
\text { surface and few open dentinal tubules. }\end{array}$ \\
\hline 4 & $\begin{array}{l}\text { Walls with debris clusters covering } \\
\text { more than } 50 \% \text { of the surface. }\end{array}$ & $\begin{array}{l}\text { Walls completely covered by smear and } \\
\text { absence of open dentinal tubules. }\end{array}$ \\
\hline 5 & Walls completely covered by debris. & --- \\
\hline
\end{tabular}

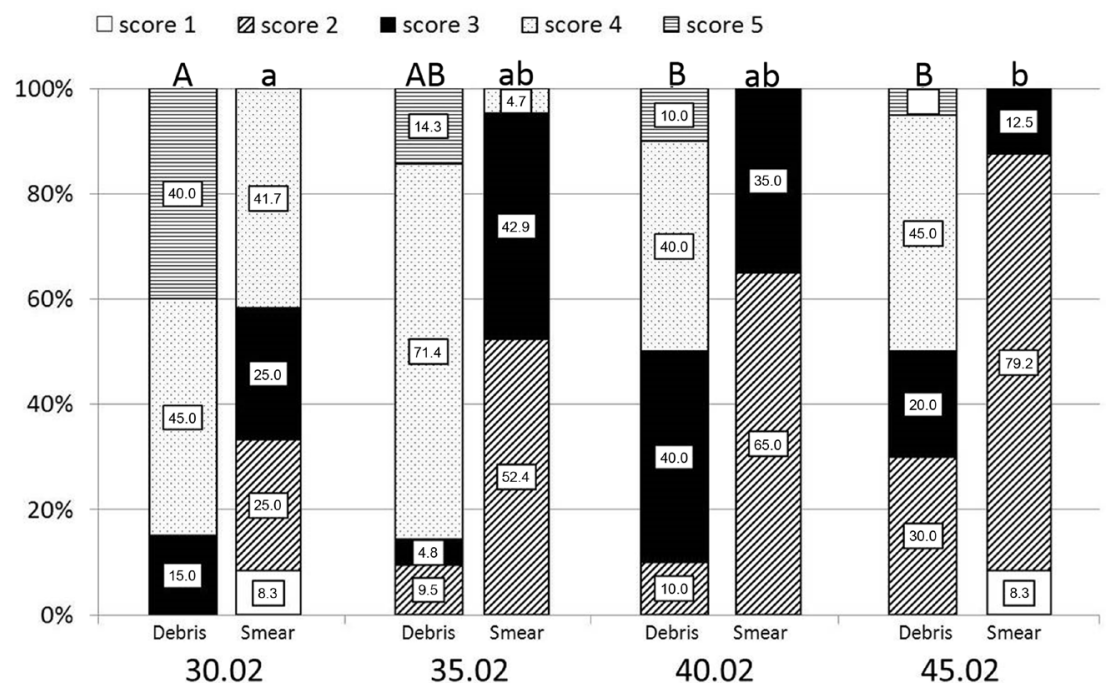

Figure 1. Percent distribution of scores, according to instrumentation protocols, attributed to removal of debris and smear layer. Different letters indicate statistically significant difference (Dunn's test, $\alpha=5 \%$ ). Capital letters refer to debris and lowercase letters refer to smear. performed using $1 \mathrm{~mL}$ of $1 \% \mathrm{NaOCl}$, followed by aspiration with Capillary Tips and subsequent irrigation with $10 \mathrm{~mL}$ of distilled and deionized water.

The roots were analyzed in a scanning electron microscope (JSM JEOL - model 5410, Tokyo, Japan) for the presence of debris $(35 x)$ and smear layer (1000x) in the apical, middle and cervical thirds. Photomicrographs of the most representative areas were evaluated in a doubleblinded mode by three calibrated evaluators in a qualitative study. The scores used in this study were adapted from those proposed by Hulsmann et al. (9) and are shown in Table 1.

Kappa coefficient was used to test inter- and intraexaminer reproducibility using the criteria proposed by Landis and Koch (10). Statistical analysis was performed by Kruskal-Wallis and post hoc Dunn's tests $(\alpha=5 \%)$ using SPSS 17.0 software (IBM, New York, NY, USA).

\section{Results}

The inter- and intra-examiner Kappa coefficients were 0.76 (0.685 to 0.844$)$ and 0.88 (0.8564 to 0.9356), respectively, and the reproducibility classified as good (10).

Figure 1 shows the percentage of scores assigned to removal of debris and smear layer, according to each instrumentation protocol.

Comparing debris removal and considering the entire root canal, statistical difference among the instrumentation groups $(p<0.05)$ was demonstrated, with the 30.02 and 35.02 groups showing more debris and statistically similar between them $(p>0.05)$, and different from the 40.02 and the 45.02 groups $(p<0.05)$, in which less debris were found.

Regarding the cleaning according to the thirds of the root canal, statistical difference was found only in the middle third $(\mathrm{p}<0.05)$, where the 30.02 group showed less clean areas and was significantly different from the 40.02 group $(p<0.05)$. In the cervical and apical thirds, no statistical difference among the tested groups ( $p>0.05$ ) was found.

Considering smear removal, statistical difference among the groups $(\mathrm{p}<0.05)$ was observed, with the 30.02 group showing the highest scores, statistically different when 
compared to the 45.02 group $(\mathrm{p}<0.05)$, and similar to the 35.02 and 40.02 groups ( $p>0.05)$.

When presence of the smear layer was observed in the root thirds, only the 30.02 group was different from the 45.02 group $(p<0.05)$ in statistical terms, and solely at the cervical third.

\section{Analysis of the Photomicrographs Obtained by SEM}

In the root canals prepared up to the final diameter of 30.02, the analysis of photomicrographs at $35 x$ magnification showed increased agglomeration of debris, covering more than $50 \%$ of the canal surface, regardless of the analyzed third (Figs. 2A, 2C and 2E). When the specimens were evaluated at a 1000x magnification, smear layer covering approximately the entire surface was observed with no visible dentinal tubules (Figs. 2B, 2D and 2F).

In the root canals prepared up to the final diameter of 35.02, debris could be observed covering more than half of the dentin surface (Figs. 3A, 3C and 3E). Regarding the smear layer, most of the dentin surface was coated, but with areas of visible dentinal tubules (Figs. 3B, 3D and 3F).

Considering the root canals prepared with the 40.02 final diameter, cleaner areas were observed, often with more than $50 \%$ of the dentin surface without debris (Figs. 4A, 4C
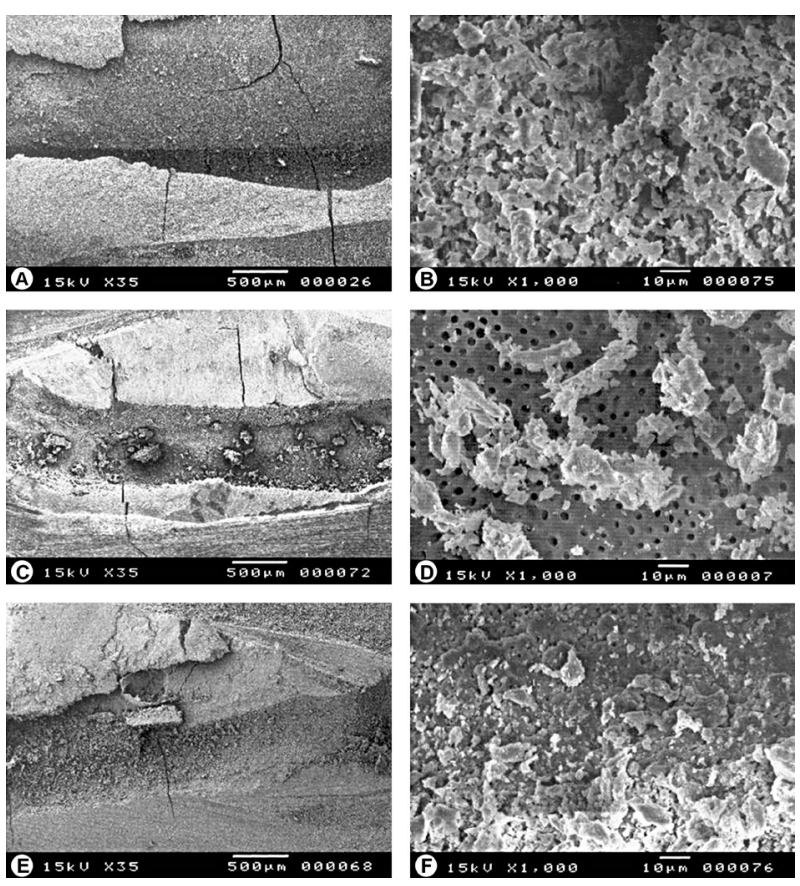

Figure 2. SEM micrographs representative of the 30.02 group. A: Apical third with presence of debris along canal $(35 \times)$. B: Apical third with smear layer completely covering all dentinal tubules (1000x). C: Middle third with the presence of debris with several clusters over canal (35x). D: Middle third with smear layer and partially occluded tubules (1000x). E: Cervical third with agglomeration of debris in the canal lumen (35x). F: Cervical third with smear layer and few visible dentinal tubules (1000x). and 4E) At higher magnification, in various specimens the dentin surface presented smear layer covering $50 \%$ of the area and several open dentinal tubules (Figs. 4B, 4D and 4F).

In specimens that had their root canals prepared with the highest final diameter, corresponding to 45.02, debris clusters were observed, covering half the surface (Figs. $5 \mathrm{~A}, 5 \mathrm{C}$ and $5 \mathrm{E})$. Regarding the smear layer, cleaner areas prevailed, with smear layer-free surfaces and open dentinal tubules (Figs. 5B, 5D and 5F).

\section{Discussion}

Regarding debris removal, the results of this study demonstrated that increased apical diameter associated with apical negative pressure irrigation provided better cleaning results. More clean areas were observed, regardless of the root third, when the instruments 40.02 and $\mathbf{4 5 . 0 2}$ were used, often with more than half the dentin surface without debris.

These results are consistent with studies that used similar SEM analysis $(6,11,12)$ and can be explained by the regularity of the root walls, irrigating flow and contact time of the solution with the canal. When the canal was instrumented up to 40.02 and 45.02 diameters, a higher regularity on root canal walls was observed. According

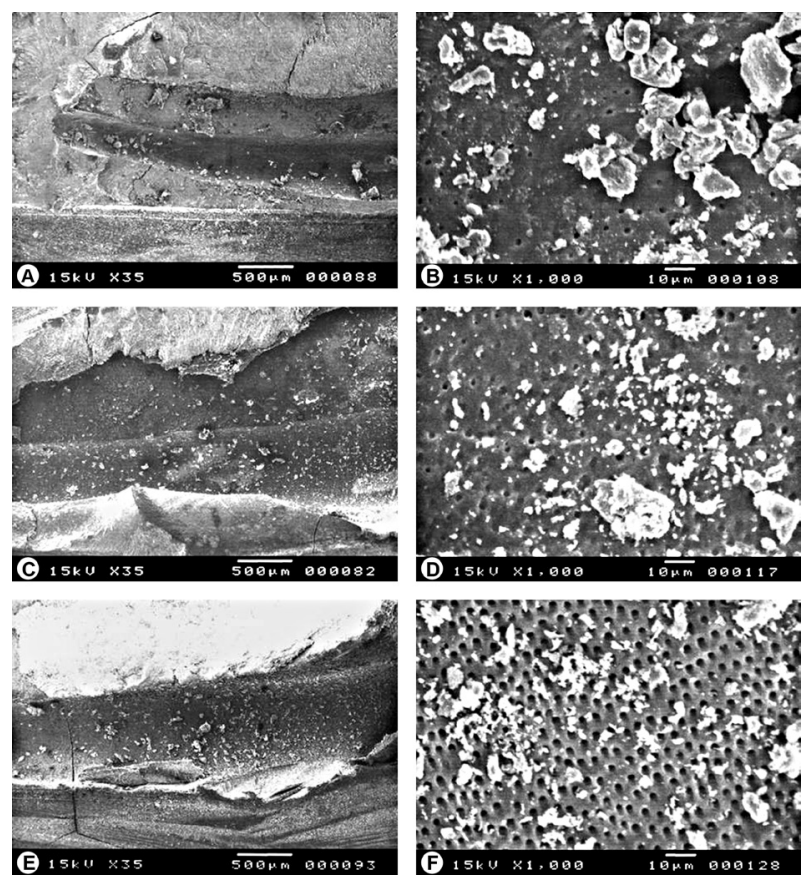

Figure 3. SEM micrographs representative of group 35.02. A: Apical third with presence of debris along canal $(35 x)$. B: Apical third with smear layer and partially obliterated tubules (1000x). C: Middle third with presence of debris throughout canal (35x). D: Middle third with smear layer and partially obliterated tubules (1000x). E: Cervical third with clusters of debris in the canal lumen $(35 x)$. F: Cervical third with smear layer and partially occluded tubules (1000x). 
to Wu et al. (13), the molar anatomical diameter has an average of 25 to 30 microns and thus, the 40 and 45 instruments exhibit greater effectiveness on the dentin surface, removing 100 to $150 \mu \mathrm{m}$ dentin from the canal walls. On the other hand, the 30.02 instrument was not able of providing adequate regularization of the root wall, probably due to the poor performance of the instrument.

Besides the increased surgical diameter, apical negative pressure irrigation probably collaborated with the cleanliness obtained in this study, since it allows greater removal of debris from areas untouched by the instruments, when compared with other irrigation protocols $(6,12,14,15)$.

Another important factor was the use of sodium hypochlorite solution, which favored the dissolution of organic tissue, facilitating the cleaning of the root canal by the transformation of insoluble substances (pulp tissue and necrotic debris) into soluble products, such as soaps, chloramines and amino acid salts. The action of soaps produced in the chemical reaction maintains greasy bodies in suspension (micelles), likely to be aspirated (5), which results in the removal of debris from the root canal.

With respect to smear layer, there was a statistically significant difference when the apical preparations performed with 30.02 and 45.02 diameters were compared, since the 35.02 and 40.02 diameters showed intermediate
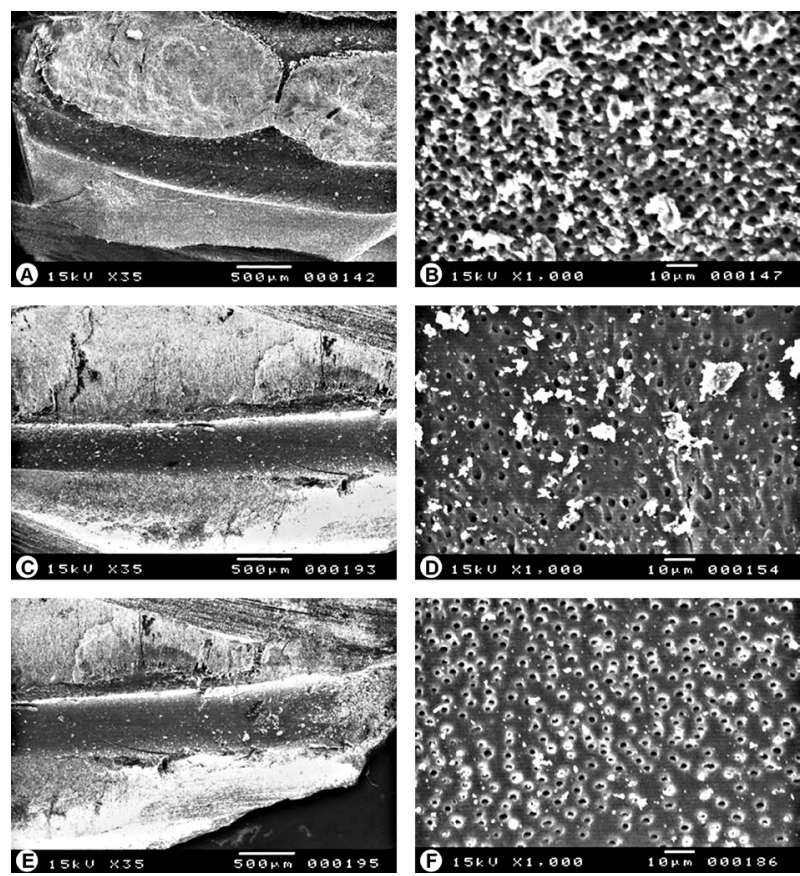

Figure 4. SEM micrographs representative of group 40.02. A: Apical third with presence of debris along canal $(35 \times)$. B: Apical third with smear layer and partially obliterated tubules (1000x). C: Middle third with presence of debris $(35 x)$. D: Middle third with smear layer and partially occluded tubules $(1000 \times)$. E: Cervical third with agglomeration of debris in the canal $(35 \times)$. F: Cervical third with few smear layer and some partially obliterated tubules (1000x). values. Qualitative analysis revealed a predominance of cleaner areas, with approximately half the surface without smear layer and several open dentinal tubules when the 45.02 diameter was employed.

These results agree with those of previous studies $(16,17)$ which suggested that the higher enlargement in the apical portion of molar canals could be advantageous, since it would allow a higher probability of touching the dentin walls with the instruments.

Thus, the results of this study are probably due to the greater volume of the used solution, owing to increased surgical diameter and, consequently, to the higher enlargement of the root canal, which provided a greater flow rate to the irrigating solution. According to Brunson et al. (18), the volume and flow of irrigating solution are directly related to the effectiveness of root canal cleaning together with the mechanical instrumentation.

Removal of the smear layer may also be ascribed to the chelating action of EDTA and the contact time of the solution with the dentinal walls. In this study EDTA was used for $5 \mathrm{~min}$, differently from Ribeiro et al. (6) who used EDTA for $1 \mathrm{~min}$ and failed to remove smear layer.

The results of the current study suggest the use of the 40.02 and the 45.02 instruments for surgical diameter enlargement of curved molar canals, as it was emphasized by
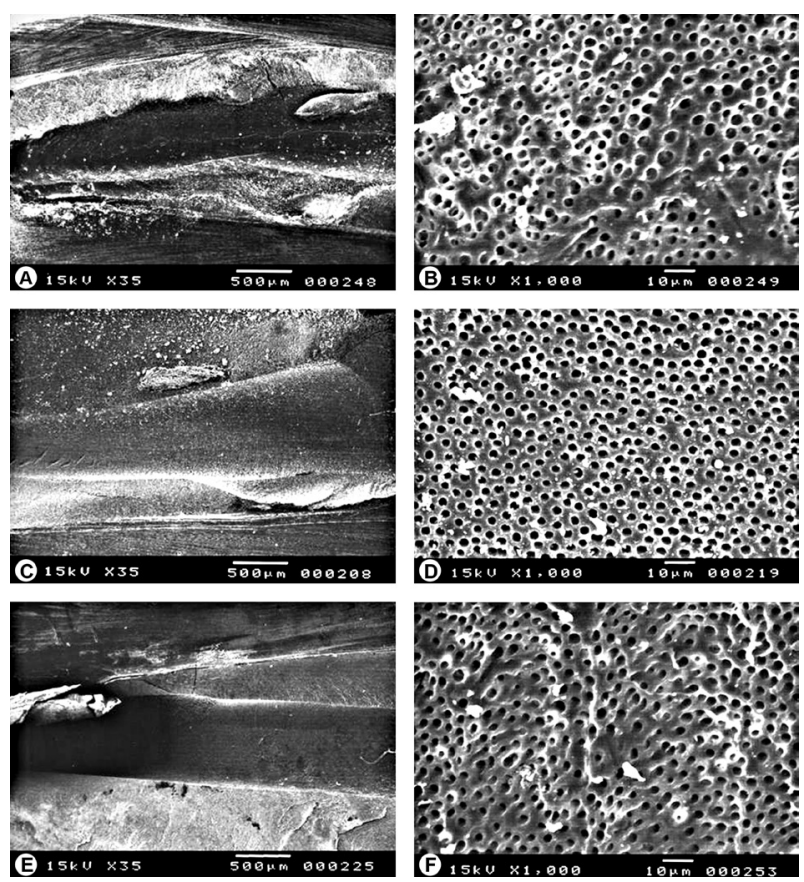

Figure 5. SEM micrographs representative of group 45.02. A: Apical third with presence of debris along canal (35x). B: Apical third with little smear layer and open dentinal tubules (1000x). C: Middle third with presence of debris $(35 \times)$. D: Middle third with little smear layer and open dentinal tubules (1000x). E: Cervical third with few clusters of debris in the canal $(35 x)$. F: Cervical third almost smear-free surface and open dentinal tubules (1000x). 
Fornari et al. (2) and Gregorio et al. (19). These instruments may also improve the cleaning of the apical third, due to the increased regularization of the root canal walls, but without causing apical transportation (1).

Although none of the tested final diameters was able to completely remove the debris and smear layer from the root canals with moderate curvature, the 40.02 and 45.02 diameters showed the best results, both in relation to the removal of debris and the smear layer.

\section{Resumo}

Este estudo buscou avaliar, por meio de microscopia eletrônica de varredura (MEV), a limpeza das paredes de canais com curvatura moderada, submetidos ao preparo biomecânico com diferentes diâmetros finais utilizando-se irrigação por pressão apical negativa. Trinta e duas raizes mésio-vestibulares de molares foram divididas em 4 grupos $(n=8)$ de acordo com o diâmetro final dos instrumentos: GI: 30.02, GII: 35.02, GIII: 40.02 e GIV: 45.02 . 0 procedimento de irrigação foi realizado a cada troca de instrumento com NAOCl 1\% utilizando o sistema EndoVac. A irrigação final foi conduzida com EDTA 17\% por 5 min. As microfotografias de MEV foram avaliadas sob aumentos de $35 \times$ e $1000 x$, por três examinadores calibrados, em estudo duplo-cego. Os dados foram submetidos ao teste de Kruskal-Wallis e pós-teste de Dunn $(\alpha=0,05)$. 0 s canais instrumentados com diâmetros finais de 30.02 e 35.02 demonstraram mais debris, estatisticamente diferente dos demais grupos $(p<0,05)$. Comparando-se cada terço do canal radicular, para as porções cervical e apical não foi encontrada diferença estatisticamente significante $(p>0,05)$ entre os quatro grupos. Com relação à presença de smear layer, canais com diâmetro final de 30.02 demonstraram os maiores scores, estatisticamente diferente do grupo $45.02(p<0,05)$ e similar aos grupos 35.02 e $40.02(p>0,05)$. Apesar de nenhum dos diâmetros estudados ter removido completamente os debris e a smear layer, pode ser concluido que a instrumentação com diâmetros finais maiores foi mais efetiva na limpeza dos canais radiculares com curvatura moderada.

\section{References}

1. Pasternak-Junior B, Sousa-Neto MD, Silva RG. Canal transportation and centering ability of RaCe rotary instruments. Int Endod J 2009;42:499506.

2. Fornari VJ, Silva-Sousa YTC, Vanniz JR, Pécora JD, Versiani MA, SousaNeto MD. Histological evaluation of the effectiveness of increased apical enlargement of cleaning the apical third of curved canals. Int Endod J 2010;43:988-994.

3. Peters $\mathrm{OA}$, Schonenberger $\mathrm{K}$, Laib A. Effects of four Ni-Ti preparation techniques on root canal geometry assessed by micro computed tomography. Int Endod J 2001;34:221-230.

4. Oliveira CAP, Meurer MI, Pascolato C, Silva SRC. Cone-beam computed

tomography analysis of the apical third of curved roots after mechanical preparation with different automated systems. Braz Dent J 2009;20:376-381.

5. Spanó JCE, Barbin EL, Santos TC, Guimarães LF, Pécora JD. Solvent action of sodium hypochlorite on bovine pulp and physico-chemical properties of resulting liquid. Braz Dent J 2001;12:154-157.

6. Ribeiro EM, Silva-Sousa YTC, Souza-Gabriel AE, Sousa-Neto MD, Lorencetti KT, Silva SRC. Debris and smear removal in flattened root canals after use of different irrigant agitation protocols. Microsc Res Tech 2012;75:781-790.

7. Schneider SW. A comparison of canal preparations in straight and curved root canals. Oral Surg Oral Med Oral Pathol Oral Radiol Endod 1971;32,271-275.

8. Pruett JP, Clemente DJ, Carnes DL. Cyclic fatigue testing of nickel titanium endodontic instruments. J Endod 1997;23:77-85.

9. Hülsmann M, Rümmelin C, Shäfers F. Root canal cleanliness after preparation with different endodontic handpieces and hand instruments: a comparative SEM investigation. Int Endod J 1997;23:301-306.

10. Landis JR, Koch GG. The measurement of observer agreement for categorical data. Biometrics 1977;33,159-174.

11. Caron G, Nham K, Bronnec F, Machtou P. Effectiveness of different final irrigant activation protocols on smear layer removal in curved canals. J Endod 2010;36:1361-1366.

12. Al-Ali M, Sathorn C, Parashos P. Root canal debridement efficacy of different final irrigation protocols. Int Endod J 2012;45:898-906.

13. Wu MK, Barkis D, Roris A, Wesselink PR. Does the first file to bind correspond to the diameter of the canal in the apical region? Int Endod J 2002;35:264-267.

14. Susin L, Liu Y, Yoon JC, Parente JM, Loushine RJ, Ricucci D, et al.. Canal and isthmus debridement efficacies of two irrigant agitation techniques in a closed system. Int Endod J 2010;43:1-14.

15. Goode N, Khan A, Eid AA, Niu LN, Gosier J, Susin LF, et al.. Wall shear stress effects of different endodontic irrigation techniques and systems. J Dent 2013;41:636-641.

16. Hülsmann $M$, Gressmann $G$, Schäfers $F$. A comparative study of root canal preparation using Flexmaster and HERO 642 rotatory NI-TI instruments. Int Endod J 2003;36:358-366.

17. Guelzow A, Stamm O, Martus P, Kielbassa AM. Comparative study of six rotary nickel-titanium systems and hand instrumentation for root canal preparation. Int Endod J 2005;38:743-752.

18. Brunson M, Heilborn C, Johnson J, Cohenca N. Effect of apical preparation size and preparation taper on irrigant volume delivered by using negative pressure irrigation system. J Endod 2010;36:721-724.

19. Gregorio C, Paranjipe A, Garcia A, Navarrete N, Estevez R, Esplugues $E O$, et al.. Efficacy of irrigation systems on penetration of sodium hypochlorite to working length and to simulated uninstrumented areas in oval shaped root canals. Int Endod J 2012;45:475-481.

Received March 28, 2014 Accepted October 6, 2014 